\title{
運動鐉練者に検出される特異血浆蛋白兵
}

\author{
弘卓 三* 門 福 強 樹** 牧 野 義 彰* \\ 佐 藤 永 雄 ${ }^{* *}$ 紺 野 邦 夫*

\section{SPECIFIC PLASMA PROTEIN DETECTED ON PHYSICAL EDUCATION ATHLETIC STUDENTS}

\author{
Takumitsu Hiro, Tsuyoki Kadofuku, Yoshiaki Makino, \\ Tsuneo Sato and Kunio Konno
}

\begin{abstract}
The purpose of this study is to analyze the plasma proteins of physical education athletic and general students (aged 19-22) before their breakfast by two-dimensional electrophoresis.

The results of this study, a protein which has not been found in any original report yet is detcted from physical education athletic students before breakfast.

This protein was not detected from general studenets before breakfast. This protein was detected at the position of pI 5.0, molecular weight of about 70,000 on two-dimensional polyacrylamide gel electrophosis under non-denaturing codition, but it showed a molecular weight of about 30,000 on SDS-polyacrylamide gel electrophoresis.

As far as this research is concerned, neither special physical education athletic students and nor general students were observed in changes of two-dimensional electrophoretic patterns of blood cell cytosol and blood cell membrane proteins.

(J. Physical Fitness Japan 1986, $35: 241 \sim 247$ )

key words : athlete, plasma protein, two-dimensional polyacrylamide gel electrophoresis, SDS-polyacrylamide gel electrophoresis.
\end{abstract}

\section{I. はじめに}

我々は身体活動と健康や体力の維持増進との関 係を明らかにする目的で運動が身体におよぼす影

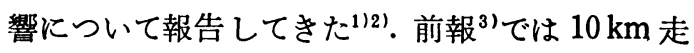
前後の血墏を 2 次元電気泳動法で分析し, 運動後 特異的に出現する蛋白質が存在することを報告し た.しかし，この場合対象者は体育専攻学生およ びその大学院生でありスポーツ実践者のみに特異 的に出現するものか, あるいは一般人にも出現す るものかについては明らかでなかった.

そこで今回は $10 \mathrm{~km}$ 走後の血漿中に特異的に 出現する蛋白質の性質についての研究を行なう手 始めとして，継続的な運動を実施している人と実 施していない人の早朝空腹時の血漿蛋白質を 2 次
元電気泳動法で分析し, 我々が $10 \mathrm{~km}$ 走後の 血 墏中から検出した特異蛋白質と同じ蛋白質が存在 するか否かについて検討した。

\section{II. 試料および方法}

\section{A. 実験对象}

対象は継続的な運動を実施している某体育大学 長距離部員 6 名 (以下スポーツ選手, athlete とす る）および継続的な運動を実施していない大学生 6 名 (以下一般人, non-athlete とする) であり, 年令はいずれの群とも19 22才の健康な男子であ った。

\section{B. 採血および試料の調製}

採血は早朝空腹時に座位安静にて正中皮静脈よ り約 $10 \mathrm{ml}$ ，ヘパリン加工させた真空採血管を用

\footnotetext{
* 昭和大学医学部第 1 生化学教室 Department of Biochemistry, School of Medicine, Showa

** 昭和大学医学部第 2 生化学教室 東京都品川区旗の台 1-5-8 
いて行った.

血液は $3,000 \times \mathrm{g} ・ 10$ 分間の遠心を行い, その上 清に $10 \%$ ショ糖となるようにショ糖を加えたもの を血漿蛋白試料とした。

\section{C. 樲 落}

両性担体は LKB の $\mathrm{pH} 3.5 \sim 10$ および $\mathrm{pH} 4.0$ 〜6.5のアンフォラインを用いた. アクリルアミ ド， $\mathrm{N}, \mathrm{N}$-メチレンビスアクリルアミド， $\mathrm{N}, \mathrm{N}$, $\mathrm{N}, \mathrm{N}$-テトラメチルェチレンジアミン(以上電気 泳動用特製試薬), SDS, 2-メルカプトエタノール (以上生化学用試薬), トリス, グリシン, 過 硫酸 アンモニウム (以上特級試薬) は和光純薬のもの を使用した. コマジーブリリアントブルー R-250 は Sigma のものを使用した。

\section{D. 方 法}

1. 血漿の 2 次元電気泳動

血漿の 2 次元電気泳動は Kadofuku たち"の方 法に準じて行った. 1 次元目のゲルは内径 $0.5 \mathrm{~cm}$, 長さ $20 \mathrm{~cm}$ のガラス管を用い, $4 \%$ アクリルアミ ド, $0.2 \% \mathrm{~N}, \mathrm{~N}$-メチレンビスアクリルアミド, $2 \%$ ンフォライン, $0.03 \%$ TEMED, $0.07 \%$ 過 硫酸アンモニウムによって作製した，電極槽液は 陽極側を $0.01 \mathrm{M}$ リン酸, 陰極側を $0.1 \mathrm{M} \mathrm{NaOH}$ とし $4{ }^{\circ} \mathrm{C} て ゙ 20$ 時間の泳動を行った. 2 次元目は幅 $16 \mathrm{~cm}$, 長さ $14 \mathrm{~cm}$, 厚さ $0.4 \mathrm{~cm}$ の $21 \%$ の直 線濃度勾配ポリアクリルアミドスラブゲルとし た. 濃度勾配ゲルの組成は高濃度溶液を $0.375 \mathrm{M}$ Tris- $\mathrm{HCl}(\mathrm{pH} 8.9), 21 \%$ アクリルアミド, $0.2 \% \mathrm{~N}$, N'-メチレンビスアクリルアミド, $10 \%$ ショ糖, 0.03\% TEMED, $0.03 \%$ 過硫酸アンモニウム，お よび低濃度溶液を $0.375 \mathrm{M}$ Tris- $\mathrm{HCl}(\mathrm{pH} 8.9), 4 \%$ アクリルアミド, $0.2 \% \mathrm{~N}, \mathrm{~N}$-メチレンビスアク リルアミド, $0.03 \%$ TEMED, $0.03 \%$ 過硫酸アン モニウムとし, 濃度勾配作製装置を用いて流速 $3 \mathrm{ml} / \mathrm{min}$ で作成した。

泳動用緩衡液は $0.05 \mathrm{M}$ Tris- $0.38 \mathrm{M}$ グリシン （pH 8.3）を用い， 4 C Cで20時間の泳動を行った.

2. $\mathrm{pH}$ 勾配および分子量測定

$\mathrm{pH}$ 勾配は 1 次元目の等電点電気泳動を各試料 2 本ずつ行い，そのうちの 1 本を電気泳動終了直 後 $10 \mathrm{~mm}$ ずつ切り取って, 蒸留水 $1 \mathrm{ml}$ ずつ加え

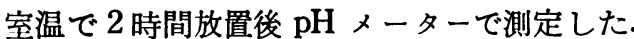

SDS 電気泳動による蛋白質の分子量 测 定に は cytochrome $C(12,400)$, carbonic anhydrase $(30,000)$, ovalbumin $(45,000)$, bovine serum albumin $(68,000)$, phospholylase a $(94,000)$, rabbit muscle myosin $(220,000)$ を標準蛋白質として使 用した。

3. 染色および脱染色

電気泳動後のゲルは $0.025 \%$ コマジーブリリア ントブルーR-250，50\%×タノール，7\%酢酸中で 1 晚染色した．脱染色は $30 \%$ メタノール，7\%酢 酸で行った。

4. 血液有形成分および血清浸透圧の分析 血液有形成分(赤血球数, 白血球数, 平均赤血球 容積，へマトクリット值，血色素量，網状赤血球） は Coulter Electric のCoulter Counter で分析し た.また，血清浸透圧は氷点降下法で分析した。

\section{III. 結果}

表 1 には被検者の身体特性を示した。 $\dot{\mathrm{V}} \mathrm{O}_{2} \mathrm{max}$

Table 1. Characteristics of subjects $(n=6)$

\begin{tabular}{lcc}
\hline & Non-Athletes & Athletes \\
\hline Age (years) & $19.9 \pm 0.8$ & $20.2 \pm 1.1$ \\
Height $(\mathrm{cm})$ & $171.8 \pm 4.0$ & $170.3 \pm 5.7$ \\
Weight $(\mathrm{kg})$ & $57.3 \pm 7.6$ & $57.6 \pm 5.8$ \\
$\dot{\mathrm{V}} \mathrm{O}_{2} \mathrm{Max} .(1 / \mathrm{min})$ & $2.34 \pm 0.35$ & $3.86 \pm 0.60^{*}$ \\
\hline
\end{tabular}

Level of significance; ${ }^{*} \mathrm{p}<0.01$ from non-athletes

Table 2. Conparisons of blood properties and osmotic pressure before breakfast

\begin{tabular}{|c|c|c|}
\hline & Non-Athletes & Athletes \\
\hline $\mathrm{RBC}\left(\times 10^{4} / \mathrm{mm}^{3}\right)$ & $516 \pm 37$ & $486 \pm 34$ \\
\hline $\begin{array}{l}\text { WBC } \\
\qquad\left(\times 10^{2} / \mathrm{mm}^{3}\right)\end{array}$ & $63 \pm 6$ & $69 \pm 15$ \\
\hline $\mathrm{Ht}(\%)$ & $47.1 \pm 3.8$ & $43.0 \pm 2.7^{*}$ \\
\hline $\mathrm{Hb}(\mathrm{g} / \mathrm{dl})$ & $15.3 \pm 1.4$ & $14.2 \pm 0.9$ \\
\hline $\operatorname{MCV}\left(\mu \mathrm{m}^{3}\right)$ & $91.6 \pm 3.2$ & $87.5 \pm 2.7^{*}$ \\
\hline Reticulocyte $(\%)$ & $7.6 \pm 2.1$ & $14.1 \pm 5.8^{*}$ \\
\hline $\begin{array}{r}\text { Osmotic Pressure } \\
(\text { Mos/L) }\end{array}$ & $291 \pm 15$ & $292 \pm 11$ \\
\hline
\end{tabular}

Level of significance of difference ; ${ }^{*}<<0.05$ from non-athletes. 
Non-
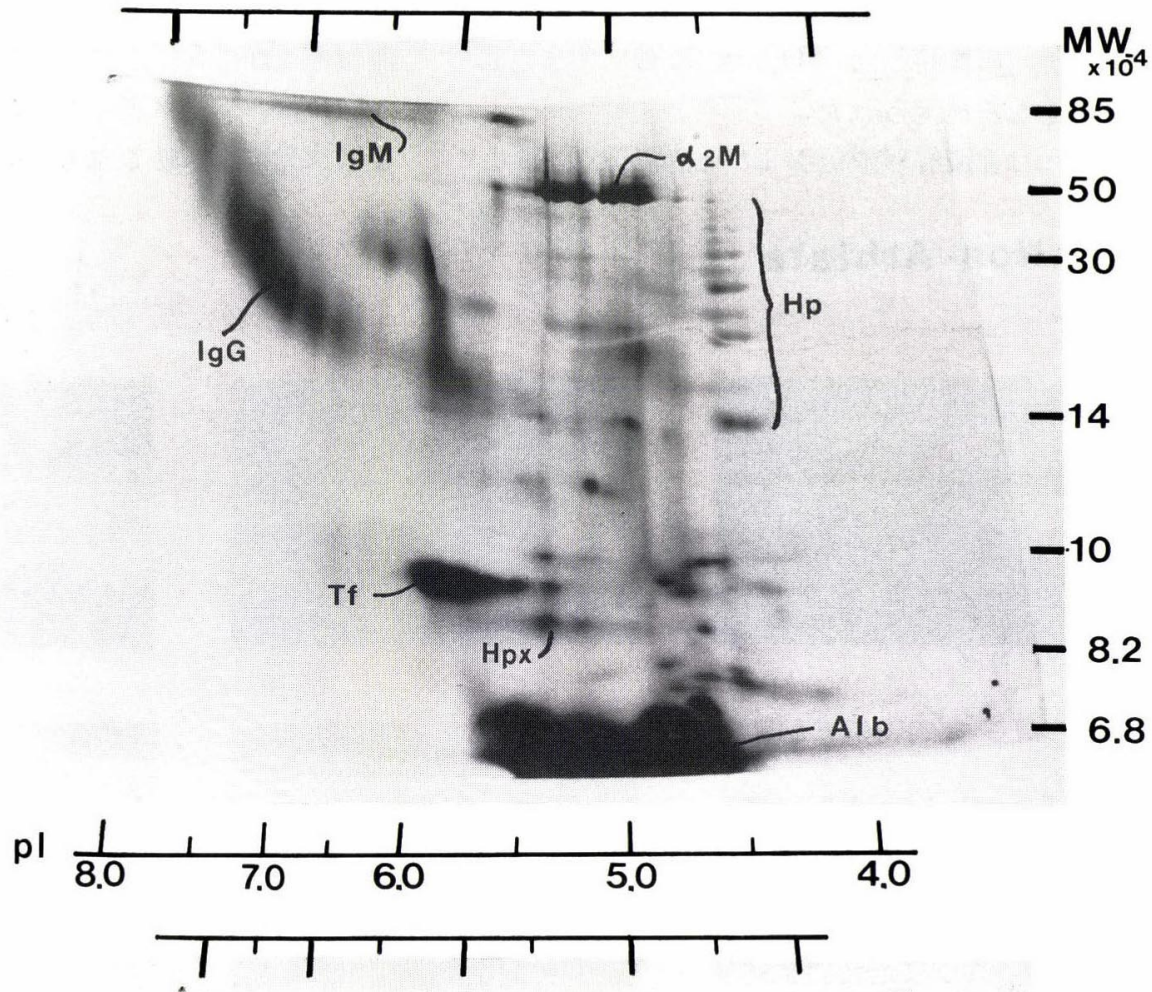

\section{Athlete}

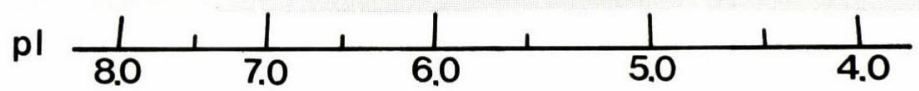

Fig. 1. Typical two-dimensional electrophoretic patterns of plasma proteins in athletes and non-athletes before breakfast. Protein which remarkably appeared in athletes was indicated by arrow. Ig $M$ : immunoglobulin $M, \operatorname{IgG}:$ immunoglobulin $G, \alpha_{2} M: \alpha_{2}$-macroglobulin, Hp : haptoglobin, Tf : transferrin, Alb : albumin. 
は自転車エルゴメーターによる最大下作業によっ て求めた. 両群間には $\dot{\mathrm{V}}_{2} \max$ に和いて $1 \%$ 水 準で有意な差が得られた。

表 2 には血液有形成分および血清浸透圧を示し
た. 両群間でへマトクリット, 平均赤血球容積, 網状赤血球に $5 \%$ 水準で有意な差が得られた.

㘠1 はスポーツ選手および一般人の血漿蛋白質 を2 次元電気泳動したものの各 1 例ずつを示した

\section{Non-Athlete}

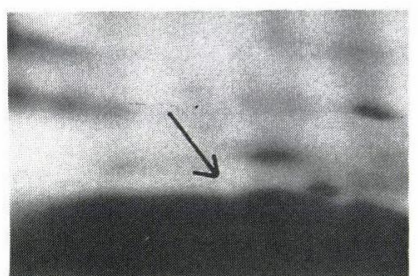

N.K.

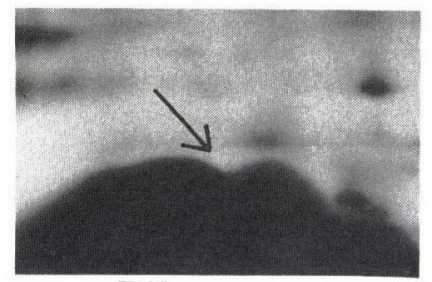

T.K.

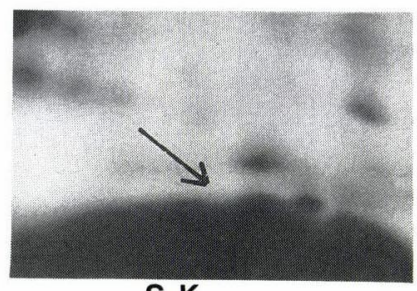

S.K.

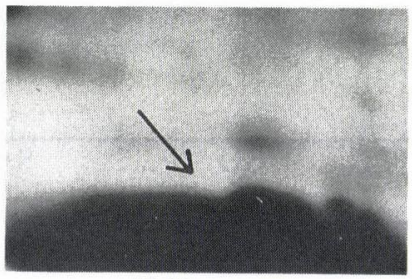

K.U.

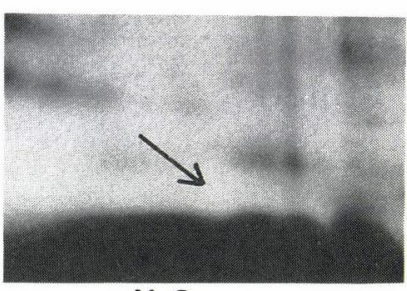

N.S.

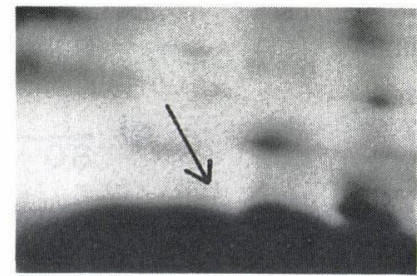

S.N.

\section{Athiete}

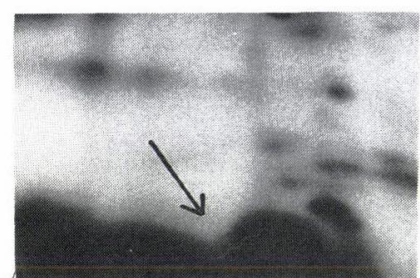

T.K.

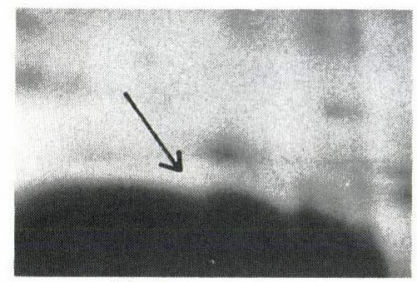

M.A.

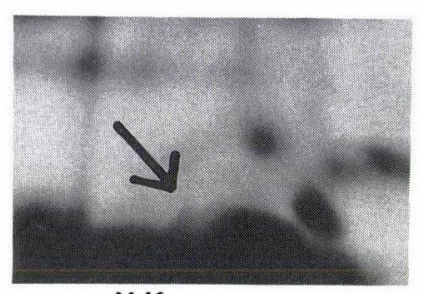

Y.K.

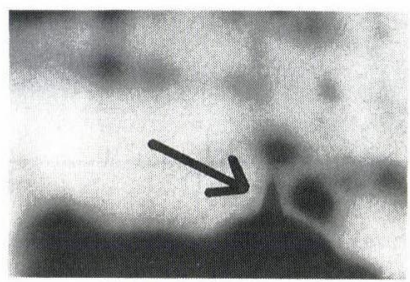

M.U.

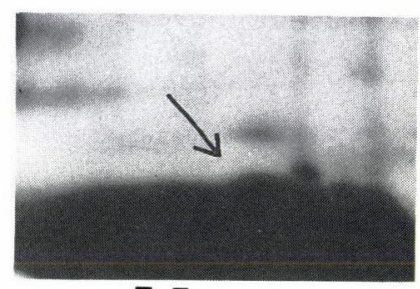

T.F.

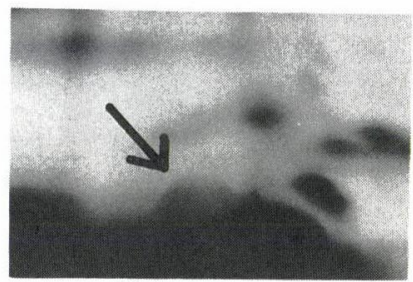

S.I.

Fig. 2. Two-dimensional gel sections containing the plasma protein remarkably appeared in athletes. The area and the position in two-dimensional electrophoretic pattern were indicated in Fig. 1. 
ものである. 写真中には 2 次元電気泳動後の蛋白 質の位置を知るために IgM, IgG, Tf, Hp, Alb, の位置を示しだ!. 両者とも類似した泳動パター ンを示したが詳細に比較してみると一般人にはま ったく検出されなかった pI 5.0, MW 約70,000の 蛋白質がスポーツ選手からは検出された（図中矢 印).

図 2 は一般人 6 名およびスポーツ選手 6 名の被 検者全員の血墏を2次元電気泳動法で分析し pI 5.0, MW 約70,000 の部分（図1 1 黑忰で示し た）のみを示したものである。一般人においては 被検者 6 名とも矢印で示した pI 5.0, MW 約 70,000の位置にこの蛋白質をまったく検出するこ とはできなかった。しかし，スポーッ選手からは 6 名中 3 名 (太い矢印で示した Y.K., M. U., S. I.) に pI 5.0, MW 約70,000 の蛋白質を明らかに検出 することができた.なお，この蛋白質は通常の泳 動パターンとは異なりロケット状を示し，また 2 峰性を示す場合もあった。

次にスポーツ選手の早朝空腹時の血漿中に特異 的にみられる蛋白質の性質を調べるために 2 次元 電気泳動後のゲルから切り取って, SDS 電気泳動 によって分析した.すなわち, 図了に示したよう

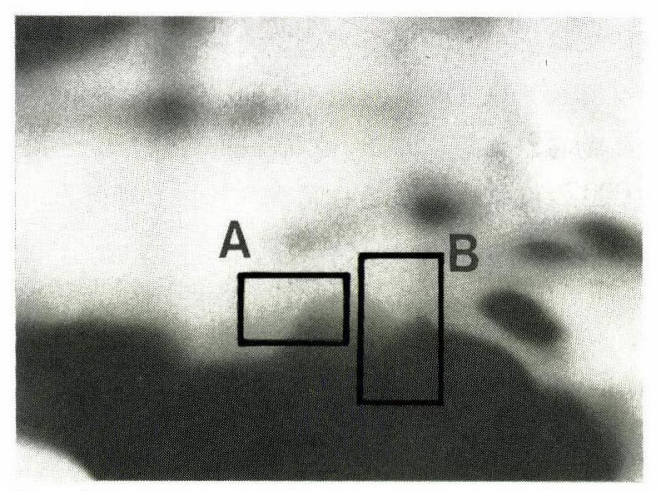

Fig. 3. Enlarged figure of two-dimensional gel section containing the protein which remarkably appeared in athletes. The proteins in area $\mathrm{A}$ and $\mathrm{B}$ were extracted from two-dimensional gel and then analyzed on SDS-polyacrylamide gel electrophoresis. A : gel section containing the protein only which appeared in athletes. B : gel section containing both the protein which appeared in athletes and albumin.

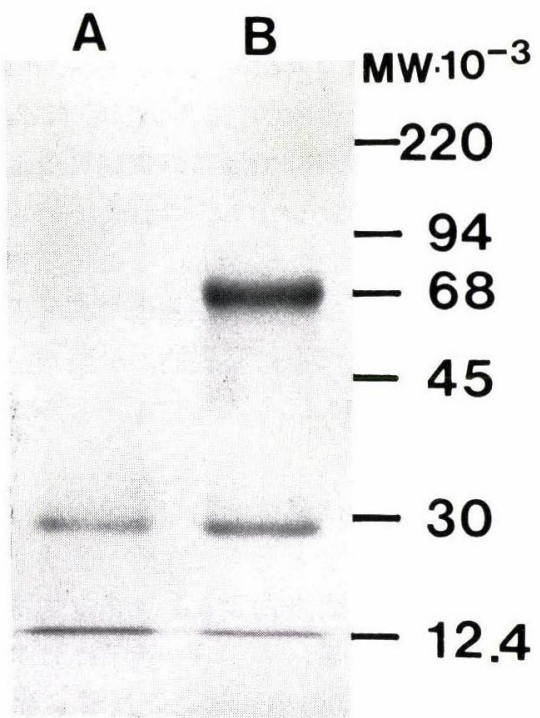

Fig. 4. SDS-polyacrylamide gel electrophoresis of the plasma protein which remarkably appeared in athletes before breakfast. A, B : see Fig. 3.

にスポーツ選手にみられる蛋白質のみが含まれる 部分を $\mathrm{A}$ ，アルブミンとその蛋白質の両方が含ま

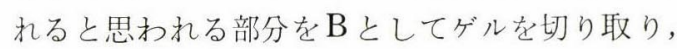

$2 \% \beta$-チオジグリコールを含む $0.1 \mathrm{~N} \mathrm{NaOH} て ゙$ 抽出後 Laemmli5 行った．その結果を示したものが㘠 4 で市る、B からはアルブミンと考えられる MW 約68,000の 主ハシンドと MW 約30,000の 2 本のバンドのみが 検出された. また，Aからは MW 約30,000のバ ンドのみがはっきりと検出された。

\section{IV. 考察}

電気泳動による蛋白質の分析法は分解能が非常 に高く, 近年生化学的研究や臨床医学の分野で も頻繁に利用されている. 特に Manabe たち6/7 はヒト血漿の蛋白質を 2 次元電気泳動しその Normalized Map を作成し，ヒト血漿蛋白質につ いての研究を行っている. Manabe たちによれば ヒト血漿蛋白質は約 250 個に分離されるが，未だ に同定されていない蛋白もあり，これらの中には 生理学的意義が不明なものもある.

先に我々は体力医学的に運動々健康や体力の維 
持增進のメカニズムを追求する目的で血漿蛋白質 を 2 次元電気泳動で分析し, 運動後特異的に増加 する蛋白質を報告した ${ }^{3 !}$.この蛋白質は等電点が 5.0, 分子量が約70,000 で通常の蛋白質の泳動像と は異なりロケット状を示し，これまで検出されて いないものであった：しかし，この時は被検者が 体育専攻学生およびその大学院生であったことか らスポーツ実践者のみに特異的に出現するもの か, あるいは一般人にもみられるものかは不明で あった。

そこで本研究では身体活動を継続的に行ってい る体育大学男子学生とそらでない一般男子大学生 の早朝空腹時の血嶈蛋白質を 2 次元電気泳動法で 分析した. その結果，スポーツ選手には 6 名中 3 名に $\mathrm{pI} 5.0, \mathrm{MW}$ 約 70,000の蛋白質が検出され, 一般人の血漿中にはこの蛋白質はまったく検出さ れなかった，さらに，前報告3!において我々は 6 名中 4 名が運動前の安静時にもこの蛋白質を検出 しており，スポーツを実施している人には早朝空 腹時や安静時にもこの蛋白質は出現していると思 われる. したがって，前報告とあわせて 2 次元電 気泳動で pI 5.0, MW 約70,000 に出現する蛋白質 は身体運動と非常に密接な関係がある蛋白質と推 測される.

この運動に関係があると考えられる蛋白質は通 常の泳動像と異なり，またアルブミンの泳動位置 と非常に近いためアルブミンに何らかの物質が結 合したものではないかと考えられたので，その部 分をゲルから取り出し SDS 電気泳動で分析した. その結果図 4 に示すごとく,この蛋白質の $\mathrm{MW}$ は 約 30,000 でありアルブミン $(68,000)$ とは異なっ たものであることが確認された.この結果は $10 \mathrm{~km}$ 走後特異的に出現する前報 ${ }^{31}$ の報告とよく 一致するものであり, 運動後特異的に出現する蛋 白質と 6 名中 3 名のスポーツ継続者の早朝空腹時 の血漿中に検出される蛋白質は明らかに同種の蛋 白質であることを示唆している.

この運動に関係あると考えられる蛋白質がどの ような運動によって出現するのか，すでに血漿中 に存在する蛋白質が他の物質と結合したためか， または組織から逸脱したものか，そしてそれが生
体内の生理的役割りとどのように関係しているか は今後の研究課題としてとらえていく必要がある と考える.

なお，早朝空腹時のスポーツ選手および一般人 の血球膜蛋白質, 血球内蛋白質の 2 次元電気泳動 も行ってみた. その結果, 血球膜蛋白質は約 120 個，血球内蛋白質は約40個の蛋白質に分離された が現在のところ両群間に顕著な差を検出すること はできなかった。

以上のごとく，現在までに同定されていない蛋 白質が身体運動の影響によって出現することは今 後の体力医学的研究を進める上でぜひ解明する必 要があると思われる.

\section{V. と め}

運動を継続的に行っている体育専攻男子大学生 6 名とそらでない一般男子大学生 6 名の早朝空腹 時の血漿蛋白質を 2 次元電気泳動法を用いて分析 し，その泳動パターンを比較した。

その結果, スポーツ選手 6 名中 3 名から現在ま でに報告のない.pI 5.0, 分子量約 70,000 の蛋白質 を検出した。 また，一般大学生からはこの蛋白質 はまったく検出されなかった：この蛋白質は通常 の蛋白質の泳動パターンとは異なるものであっ た.さらに，この蛋白質は 2 次元電気泳動ではア ルブミンとほぼ同じ位置 (pI 5.0, 分子量約70,000) に泳動されたが, SDS 電気泳動では分子量約 30,000 の位置に泳動されアルブミンとは異なった 蛋白質であった.

（受付 昭和61年 1 月 20 日）

文

1）弘 卓三(1982)：代謝性 acidosis による赤血球浸 透压脆弱性の研究. 体力科学, 31, 279-290.

2) 弘 卓三, 堀居 昭(1984): 身体トレーニングに伴 与赤血球分布曲線の研究. 体力科学, 33, 1-7.

3）弘 卓三, 門福強樹, 牧野義彰, 伀藤永雄, 紺野邦 夫(1985)：身体運動による血液成分および性状の変 化. 生物物理化学, 29, 355-362.

4) Kadofuku, T. and Sato, T.(1984): Detection of changes in rabbit serum proteins after partial 
hapatectomy by means of two-dimensional electrophoresis under non-denaturing conditions. J. Chromatogr., 311, 93-99.

5) Laemmli, U. K.(1970) : Clearge of structural proteins during the assembly of the head of bacteriophage T 4. Nature, 227, 680-685.

6) Manabe, T., Tachi, K., Kojima, K. and Okuyama T. (1979) : Two-dimensional electrophoresis of plasma proteins without denaturing agents. J. Biochem., 85, 649-659.

7) Manabe, T., Kojima, K., Jitzukawa, S., Hoshino, T. and Okuyama, T. (1981): Normalization of two-dimensional electrophoretic patterns of human plasma proteins and comparisons of cerebrospinal fluid and urine patterns in terms of the normalized map. J. Biochem., 89, 841-853. 